\title{
TOXICITY OF THE ESSENTIAL OIL OF BASIL CULTIVARS AND HYBRIDS AND ITS REPELLENT EFFECT ON STORED GRAIN PESTS
}

\author{
TOXICIDADE DO ÓLEO ESSENCIAL DE CULTIVARES E HÍBRIDOS DE \\ MANJERICÃO E SEU EFEITO REPELENTE SOBRE PRAGAS DE GRÃOS \\ ARMAZENADOS
}

\section{Andréa Santos da COSTA ${ }^{1}$; Maria de Fátima ARRIGONI-BLANK ${ }^{2}$; Leandro BACCI ${ }^{3}$; Arie Fitzgerald BLANK ${ }^{4}$; Péricles Barreto ALVES ${ }^{5}$; Magna Galvão PEIXOTO; Ane Caroline Celestino SANTOS ${ }^{7}$}

1. Doutora em Biotecnologia, Universidade Federal de Sergipe-UFS, Aracaju, SE, Brasil, deaasc@ yahoo.com.br; 2. Professora, Doutora, Departamento de Engenharia Agronômica, Universidade Federal de Sergipe-UFS, Aracaju, SE, Brasil. 3. Professor, Doutor, Departamento de Engenharia Agronômica-UFS, Aracaju, SE, Brasil. 4. Professor, Doutor, Departamento de Engenharia AgronômicaUFS, Aracaju, SE, Brasil. 5. Professor, Doutor, Departamento de Química-UFS, Aracaju, SE, Brasil. 6. Professora, Doutora, Departamento de Educação e Saúde-UFS, Campus Lagarto, SE, Brasil. 7. Doutoranda em Agricultura e Biodiversidade, Programa de Pós-Graduação em Agricultura e Biodiversidade-UFS, Aracaju, SE, Brasil.

\begin{abstract}
Essential oils have emerged as an alternative to synthetic insecticides in the control of stored grain pests. The toxicity and repellency of the essential oils of four basil cultivars and three basil hybrids and the monoterpenes linalool, citral, and (E)-methyl cinnamate were evaluated in the stored grain pests Callosobruchus maculatus and Sitophillus zeamais. The essential oils of the cultivar Genovese and the hybrid 'Genovese' x 'Maria Bonita' were more toxic to $C$. maculatus. Conversely, the essential oils of the cultivar Sweet Dani and the hybrid 'Cinnamom' x 'Maria Bonita' were more toxic to S. zeamais. Among the monoterpenes, (E)-methyl cinnamate was the most toxic to both pests, taking 0.14 and $0.34 \mu \mathrm{L} . \mathrm{mL}^{-1}$ to kill $50 \%$ of the C. maculatus and S. zeamais populations, respectively. All essential oils from cultivars, hybrids, and monoterpenes were repellent to $S$. zeamais, except for (E)-methyl cinnamate. For $C$. maculatus, this effect was lower, being citral the most repellent compound. Results demonstrate the insecticidal potential of the essential oil of $O$. basilicum and its monoterpenes in the control of stored grain pests.
\end{abstract} weevil.

KEYWORDS: Ocimum basilicum. Botanical insecticides. Monoterpenes. Cowpea seed beetle. Maize

\section{INTRODUCTION}

Post-harvest grain weight damage caused by insect-pests ranges between 20 and $60 \%$ weight losses (CASTRO-ÁLVAREZ et al., 2015). Maize weevil Sitophilus zeamais Mots. 1855 (Coleoptera: Curculionidae) and cowpea seed beetle Callosobruchus maculatus Fabr., 1775 (Coleoptera: Bruchidae) are the most concerning pests.

Maize weevil is of great relevance worldwide, attacking maize, wheat, rice, sorghum, and barley grains. Besides the direct losses due to its feeding, this insect attacks healthy grains, inside which larvae and adults feed and develop (OJO; OMOLOYE, 2012). Cowpea seed beetles are one of the most important pests of cowpea Vigna unguiculata (L.) Walp, and can also attack other grains, such as Phaseolus vulgaris (L.), Vigna radiata (L.), Glycine max 32 (L.), Lens culinaris (Medikus), Pisum sativum (L.), Vicia faba (L.), Cajanus cajan (L.), and Cicer arietinum (L.).
Chemicals of several toxicological classes are the most commonly used control method to combat these insects. This fact has led to several problems, such as the presence of high levels of residues in the grains and the emergence of resistant insect populations (RESTELLO et al., 2009; LU et al., 2013). Therefore, the development of alternative control methods with a different mode of action from that of synthetic insecticides is imperative (COITINHO et al., 2011).

The use of plants with insecticidal properties is an alternative to chemical control. They can be applied in the form of powder, extracts, and oils (ISMAN, 2006), providing greater safety, selectivity, biodegradability, economic viability, and low environmental impact (JUNIOR-VIEGAS, 2003). The essential oils of plants can act on insects in different ways, either affecting their survival or causing behavioral changes (repellency) (OLIVEIRA et al., 2018).

Ocimum basilicum L., belonging to the family Lamiaceae and popularly known in Brazil as 
basil, stands out among plants valued for their essential oil. Basil is an annual or perennial plant, depending on where it is grown. Several factors can influence the production of its essential oil, such as cultivars variety and cultivation and harvesting methods. The plant is used in cooking and as an ornamental, medicinal, and aromatic plant (BLANK et al., 2004 and 2010).

Studies have shown that the essential oil of plants of the genus Ocimum contains compounds with insecticidal (BHAVYA, CHANDU, DEVI, 2018; CHANG et al., 2009; GOMES; FAVERO, 2011), antioxidant (AVETISYAN VERIFICAR NOME DO AUTOR et al., 2017), and antimicrobial (AVETISYAN et al., 2017; OXENHAM; SVOBODA;WALTERS, 2005) action. These properties can often be attributed to the compounds found in the essential oils, such as methyl chavicol (estragole), linalool, and (E)-methyl cinnamate (BARITAUX et al., 1992, NISHIDA et al., 1984; BHAVYA, CHANDU, DEVI, 2018).

The toxicity of basil essential oil has already been confirmed against Acanthoscelides obtectus (MAZZONETTO; VENDRAMIM, 2003), Callosobruchus maculatus (PASCUALVILLALOBOS et al., 2003), Rhyzopertha dominica (LÓPEZ et al., 2008), Sitophilus zeamais (ASAWALAM et al., 2008; MATTA et al., 2010), Tribolium castaneum (MISHRA et al., 2012), Zabrotes subfasciatus (FRANÇA et al., 2012), and Sitophilus oryzae (POPOVIĆ et al., 2006). However, no research has been carried out against C. maculatus and S. zeamais and the essential oil of basil hybrids using cultivars Sweet Dani, Maria Bonita, Genovese, and Cinnamom. These essential oils appear as novelties for the essential oil market. Due to heterosis, hybrids may present unprecedented characteristics when compared with the parents in relation to the structural and functional diversity of the chemical compounds (AMARAL; SILVA, 2003), as confirmed by Costa et al. (2014 and 2016) in a study with basil hybrids.

Considering the need to prospect new plant substances that can be used in the control of stored grain pests, this study aimed to evaluate the toxicity and repellency of the essential oils of $O$. basilicum cultivars and hybrids in two important stored grain insect-pests, S. zeamais and C. maculatus.

\section{MATERIAL AND METHODS}

\section{Plant material}

Leaves of the cultivars Sweet Dani, Genovese, Cinnamom, and Maria Bonita and of the hybrids 'Cinnamom' x 'Maria Bonita', 'Genovese' x
'Maria Bonita', and 'Sweet Dani' x 'Maria Bonita' were used for essential oils extraction. Plants were cultivated at the Experimental Farm "Campus Rural UFS", harvested at three months after field cultivation, and subject to chamber drying process at $40{ }^{\circ} \mathrm{C}$ for five days.

The major compounds linalool, citral, and (E)-methyl cinnamate were obtained from the company Sigma-Aldrich (Steinheim, Germany).

\section{Extraction and analysis of essential oils}

The essential oils were extracted in the Laboratory of Plant Genetic Resources and Essential Oils of the Federal University of Sergipe by hydrodistillation in a Clevenger apparatus. Each sample was composed of $75 \mathrm{~g}$ of dried leaves, which were distilled for 120 minutes.

The volatile compounds found in the essential oils samples of $O$. basilicum were identified by gas chromatography coupled to a mass spectrometer GC-MS (model QP 5050A, Ultra, Shimadzu Corporation, Kyoto Japan), equipped with an autosampler AOC-20i (Shimadzu) and a fused silica capillary column (5\%-diphenyl-95\%dimethylpolysiloxane) of $30 \mathrm{~m} \times 0.25 \mathrm{~mm}$ i.d., 0.25 $\mathrm{mm}$ film thickness, J \& W Scientific), at a constant helium flow rate of $1.2 \mathrm{~mL} \cdot \mathrm{min}^{-1}$. The oven temperature was programmed from $50{ }^{\circ} \mathrm{C}$ (isothermal for $1.5 \mathrm{~min}$ ), with an increase of 4 ${ }^{\circ} \mathrm{C} /$ min to $200{ }^{\circ} \mathrm{C}$, then $15{ }^{\circ} \mathrm{C}$ to $250{ }^{\circ} \mathrm{C}$, ending with a $5 \mathrm{~min}$ isothermal. The injector temperature was $250{ }^{\circ} \mathrm{C}$, and the detector (or interface) temperature was $280{ }^{\circ} \mathrm{C}$. An injection volume of 0.5 $\mu \mathrm{l}$ (ethyl acetate) was employed, with a split ratio of 1:87 and column pressure of $64.20 \mathrm{kPa}$. The MS data had a quadrupole ion detector, with electron energy of $70 \mathrm{eV}$, with a scan rate of $0.85 \mathrm{scans} / \mathrm{s}$ $(\mathrm{m} / \mathrm{z}$ 40-550 Da). Gas chromatography with flame ionization detector (FID) was applied for the quantitative analysis of chemical compounds, using a Shimadzu GC- 17A (Shimadzu Corporation, Kyoto, Japan), under the following operating conditions: fused silica capillary column (5\%diphenyl-95\%-dimethylpolysiloxane, $30 \mathrm{~m} \times 0.25$ $\mathrm{mm}$ i.d., $0.25 \mathrm{~mm}$ film thickness) Phenomenex (Torrance, CA, USA), under the same conditions as described for GC-MS. Quantification of each component was calculated by area normalization (\%). Compounds concentrations were calculated from the GC peak areas and arranged in order of GC elution. The essential oil compounds were identified by comparing their mass spectra with those available in the equipment database (NIST05, NIST21, and WILEY8). These libraries enabled comparing the spectral data and the minimum 
similarity index of $80 \%$. Moreover, the retention indices measured in this experiment were compared with those in the literature (ADAMS, 2007). The relative retention indices (RRI) were determined using the Van den Dool and Kratz (1963) equation in relation to a homologous series of $n$-alkanes ${ }_{n} \mathrm{C}_{9}$ ${ }_{n} \mathrm{C}_{18}$ ), injected under the chromatographic conditions previously described.

\section{Insects}

S. zeamais and C. maculatus were collected in the city of Aracaju-SE, Brazil, and placed in plastic pots $(25 \mathrm{~cm}$ in height, $12 \mathrm{~cm}$ in diameter) containing maize or beans, in the Laboratory of Agricultural Entomology of the Federal University of Sergipe, São Cristovão-SE, Brazil.

For insect maintenance, maize grains and beans were previously kept in a freezer $\left(-10^{\circ} \mathrm{C}\right)$ for fifteen days, then washed three times with detergent and running water, and finally placed in an oven at $40^{\circ} \mathrm{C}$ for 48 hours to eliminate possible insecticide residues and organisms.

\section{Bioassays}

The essential oils of the four cultivars and the three hybrids of $O$. basilicum and the major compounds linalool, citral, and (E)-methyl cinnamate were used as treatments. Treatments were diluted in acetone (Panreac, UV-IR-HPLC-GPC PAI-ACS, 99.9\%). The control treatment consisted only of acetone application.

\section{Toxicity}

For the toxicity bioassay, the experimental design was completely randomized with three replications, using seven to 15 concentrations of the treatments, which ranged from 0.05 to $6 \mu \mathrm{L} \cdot \mathrm{mL}^{-1}$.

Each experimental unit consisted of a Petri dish $(6 \mathrm{~cm}$ in diameter $\times 1.5$ in height $)$, containing ten adult insects each. $0.4 \mathrm{~mL}$ of each concentration of the essential oils was applied to filter paper $(6 \mathrm{~cm}$ in diameter). After solvent evaporation, ten individuals of each species were added to each experimental unit. Petri dishes were maintained in a BOD at $25 \pm 5^{\circ} \mathrm{C}$, with a 12-hour photoperiod. The number of live and dead individuals was evaluated at 48 hours after application. For the toxicity evaluation, insects were considered as dead when no movements were observed.

\section{Repellency}

The $\mathrm{LC}_{50}$ of the treatments were used in the repellency bioassay, being previously obtained in the toxicity bioassays. This experiment consisted of a completely randomized experimental design with 10 replications.

Each experimental unit was composed of a Petri dish $(6 \mathrm{~cm}$ in diameter $\times 1.5$ in height) containing ten unsexed adults of $S$. zeamais and $C$. maculatus. The bottoms of the Petri dishes were covered with filter paper disks (Unifil, code 501.009), which were equally divided into treated and untreated sides (acetone). After solvent evaporation, the two sides were glued to the petri dish using double-sided adhesive tape. Repellency was evaluated at 2 and 12 hours after treatments application. The number of individuals found on each side of the Petri dish (treated and untreated sides) was recorded.

\section{Statistical analysis}

For the toxicity bioassay, treatments mortality was corrected based on the mortality of the control using the Abbott formula (1925).

Mortality data from the toxicity bioassays were subject to Probit analysis (FINEY, 1971), following the PROC PROBIT procedure of the SAS software (SAS Institute Inc, 2008). The $\chi^{2}$ test considered the curves with the acceptance probability of the null hypothesis greater than 0.05 . The lethal concentrations ( $\mathrm{LC}_{50}$ and $\mathrm{LC}_{90}$ ) were determined using these curves, with their respective confidence intervals at $95 \%$ probability.

For the repellency bioassays, the percentage data of individuals present on the untreated side of the Petri dish were subject to analysis of variance (PROC GLM, SAS) and paired t-test (PROC TTEST, SAS).

\section{RESULTS}

\section{Chemical composition of essential oils}

The chemical compositions of the essential oils of $O$. basilicum cultivars and hybrids are shown in Table 1. Forty-six compounds were identified, which represented, on average, $99 \%$ of the composition of the essential oils.

Linalool was the major compound in the essential oils of cultivars Maria Bonita and Genovese. The hybrid formed by these two cultivars also had linalool as the major compound, which presented higher concentrations. Cultivars Cinnamom and Sweet Dani had (E)-methyl cinnamate and citral (neral $=35.68 \%+$ geranial $=$ $46.16 \%$ ) as major compounds, respectively. The hybrids 'Cinnamom' x 'Maria Bonita' and 'Sweet Dani' x 'Maria Bonita' showed (E)-methyl cinnamate and linalool at higher concentrations, respectively (Table 1). 
Toxicity of the essential...

COSTA, A. S. et al.

Table 1. Chemical composition of the essential oils of basil (O. basilicum) genotypes.

Basil cultivars and hybrids

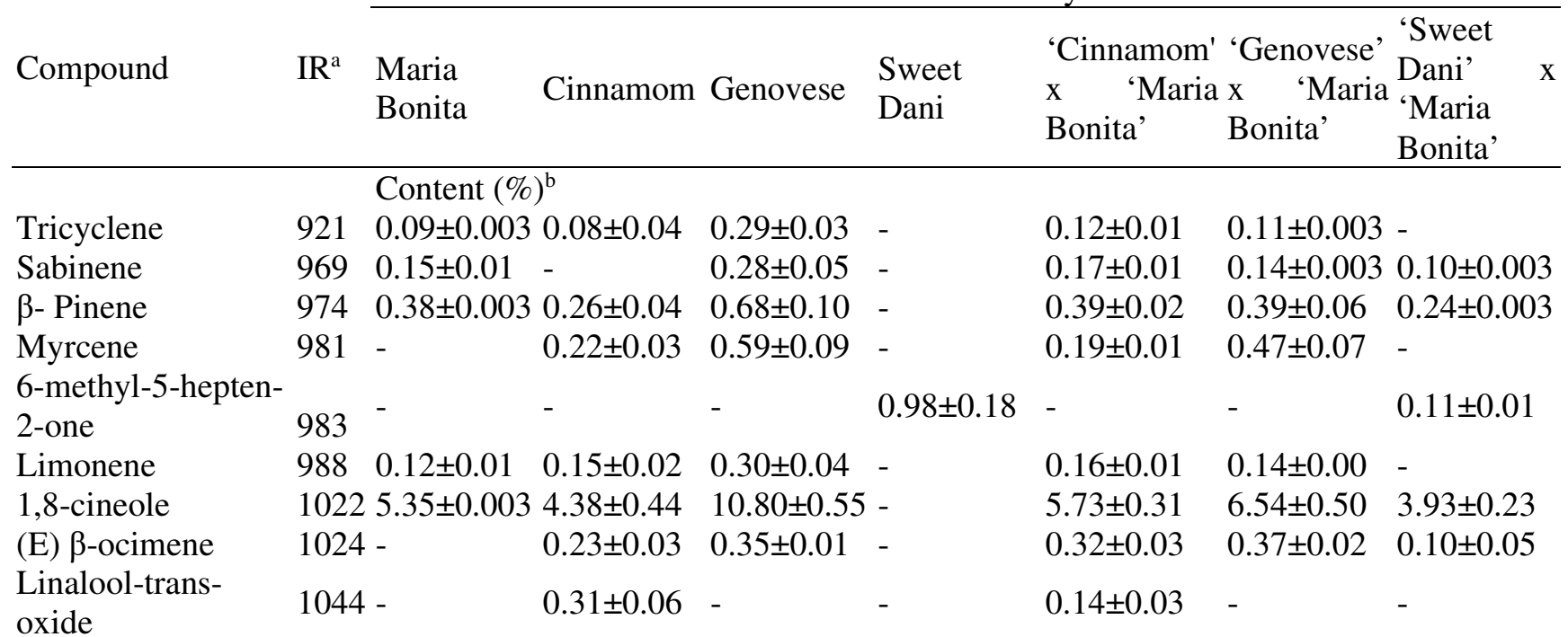

Camphor

(Z)-isocitral

Borneol

$\alpha$-terpineol

1054 75.22 $\pm 0.6130 .78 \pm 0.2065 .33 \pm 3.67-$

1095 -

$1098-$

1137 -

$0.55 \pm 0.04$

$11600.36 \pm 0.03$

Methyl chavicol

1165 -

(E)-isocitral

1177 -

Nerol

1186 -

Neral

1195 -

Geraniol

Geranial

$121114.66 \pm 0.54$ -

1227 -

Isobornyl acetate 1235 -

(Z)-methyl

cinnamate

1249 -

Eugenol

Carvacrol

1283 -

1297 -

$\begin{array}{ll}\beta \text {-elemene } & 1298 \text { - } \\ \text { Neryl acetate } & 1299 \text { - }\end{array}$

(E)-methyl

$\begin{array}{ll}- & - \\ - & 0.60 \pm 0.17\end{array}$

$35.20 \pm 1.73 \quad 56.24 \pm 0.81 \quad 55.63 \pm 1.51$

$0.26 \pm 0.02 \quad 1.05 \pm 0.06$

$0.25 \pm 0.01$

$0.47 \pm 0.03$

$0.29 \pm 0.02$

$0.26 \pm 0.09$

$-$

$1.03 \pm 0.08$

-

$\begin{array}{lll}0.34 \pm 0.05 & 0.38 \pm 0.02 & 0.30 \pm 0.01\end{array}$

$0.47 \pm 0.23 \quad 1.30 \pm 0.02 \quad 15.48 \pm 0.76-$

$3.13 \pm 0.97-$

- $\quad 0.34 \pm 0.06$

- $0.39 \pm 0.03$

$3.69 \pm 0.36 \quad 14.57 \pm 0.75$

$\mathbf{3 5 . 6 8} \pm \mathbf{0 . 7 5}-$

$0.89 \pm 0.14 \quad 0.30 \pm 0.05$

- $\quad 0.82 \pm 0.05$

$5.34 \pm 0.51 \quad 19.35 \pm 0.91$

46.16 \pm 1.45 -

$0.19 \pm 0.01$

- $\quad \overline{-} \quad-67 \pm 0.19$

-

$5.75 \pm 0.56-$

$3.91 \pm 0.89$
$0.58 \pm 0.09$
$0.79 \pm 0.35$

$\begin{array}{ll}- & 7.44 \pm 0.32 \\ - & - \\ - & - \\ - & 0.26 \pm 0.02 \\ 0.71 \pm 0.36 & -\end{array}$

$-$

$\begin{array}{ll}- & 3.91 \pm 0.89 \\ - & 0.58 \pm 0.09 \\ - & 0.79 \pm 0.35\end{array}$

cinnamate

1322 -

(E)-caryophyllene

1356 -

$\alpha$-trans-

bergamotene

a-copaene

Geranyl acetate

$\alpha$-humulene

r-muurolene

$13591.52 \pm 0.02 \quad$ -

1374 -

$13770.59 \pm 0.10$

1389 -

$\alpha$-bulnesene

$14170.32 \pm 0.01$

1432 -

$48.45 \pm 0.81-$

$43.59 \pm 1.83$

$\Upsilon$-cadinene

Neryl propanoate

$14370.49 \pm 0.01$

1452 -

Geranil propanoate 1476 -

Caryophyllene

oxide

1478 -

$\beta$-selinene

1488 -

Bicyclogermacrene 1495 -

Germacrene A 1507 -

1,10-di-epi-

1509 -

$0.36 \pm 0.03 \quad 0.51 \pm 0.11$

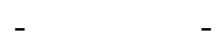

- $\quad-$

$5.11 \pm 0.07$

$1.65 \pm 0.17$

$0.79 \pm 0.04$

$0.26 \pm 0.01$

$0.36 \pm 0.14$ -

$0.45 \pm 0.08$

$1.15 \pm 0.10$

$\begin{array}{ll}1.15 \pm 0.10 & 0.39 \pm 0.06 \\ - & 1.04 \pm 0.42\end{array}$

$1.17 \pm 0.05$

$1.36 \pm 0.40$

$0.51 \pm 0.14$

$$
\text { - }
$$

$0.27 \pm 0.02$

$0.31 \pm 0.02$

$0.84 \pm 0.01$

$-$

$1.21 \pm 0.26$

$1.49 \pm 0.03-$

$0.38 \pm 0.02$

$0.54 \pm 0.05$

$0.17 \pm 0.01$

$0.32 \pm 0.07-$

$1.11 \pm 0.03$

$0.90 \pm 0.05$

$0.49 \pm 0.02$

$2.63 \pm 0.14 \quad 1.15 \pm 0.04$

$0.64 \pm 0.05$

$0.17 \pm 0.00$

$0.19 \pm 0.01$ 
cubenol

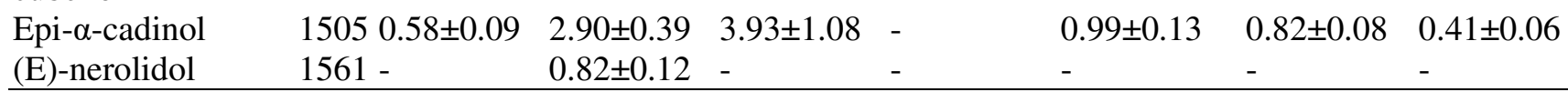

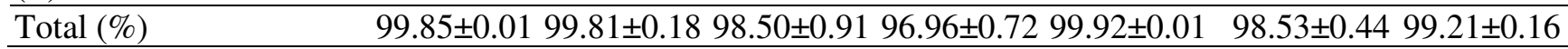

${ }^{a}$ Retention index calculated using the Van den Dool and Kratz (1963) equation for a homologous series of $n$-alkanes ( $n$ C9- $n$ C18).

b Values of the contents of the compound obtained by the mean of three different determinations obtained by GC/MS-FID. Traces indicate that the compound was not found. Bold values indicate the major compound of the essential oils.

\section{Toxicity bioassay}

Cowpea seed beetle was more susceptible to treatments than maize weevil. On average, it took 3.6 times more compounds to kill $50 \%$ of the $S$. zeamais population when compared with the $C$. maculatus population (Table 2). The lethal concentrations required to kill $50 \%$ of $C$. maculatus and $S$. zeamais populations ranged from 0.14 to 1.73 $\mu \mathrm{L} \cdot \mathrm{mL}^{-1}$ and from 0.34 to $4.14 \mu \mathrm{L} \cdot \mathrm{mL}^{-1}$, respectively (Table 2 ).

\section{Repellency bioassay}

The results of the repellency tests are shown repellent to $S$. zeamais. For $C$. maculatus, only the essential oil of cultivar Maria Bonita had a repellent effect (Figure 1). Hybrid essential oils were also repellent to both insects, except for 'Sweet Dani $\mathrm{x}$ Maria Bonita' to $C$. maculatus (Figure 1). The same repellency behavior occurred with the major compounds. The untreated side of the Petri dish exhibited more adult individuals of $C$. maculatus and $S$. zeamais when compared with the treated side, except for the compound (E)- methyl cinnamate, which did not cause repellency to $S$. zeamais (Figure 1).

in Figure 1. The essential oils of the cultivars were

Table 2. Insecticidal activity of seven $O$. basilicum essential oils and their major compounds on $C$. maculatus and $S$. zeamais adults after 48 hours of exposure.

\begin{tabular}{|c|c|c|c|c|c|}
\hline Essential oil/monoterpene & $\begin{array}{l}\mathrm{LC}_{50}\left(\mu \mathrm{L} \cdot \mathrm{mL}^{-1}\right) \\
\left(\mathrm{IC}_{95}\right)\end{array}$ & $\begin{array}{l}\mathrm{LC}_{90}\left(\mu \mathrm{L} \cdot \mathrm{mL}^{-1}\right) \\
\left(\mathrm{IC}_{95}\right)\end{array}$ & Slope & $\chi^{2}$ & $p$ \\
\hline \multicolumn{6}{|l|}{ C. maculatus } \\
\hline Maria Bonita & $\begin{array}{l}1.48 \\
(1.39-1.61)\end{array}$ & $\begin{array}{l}2.83 \\
(2.35-4.00)\end{array}$ & 4.56 & 5.71 & 0.056 \\
\hline Cinnamom & $\begin{array}{l}0.76 \\
(0.71-0.83)\end{array}$ & $\begin{array}{l}1.41 \\
(1.24-1.66)\end{array}$ & 4.59 & 5.05 & 0.078 \\
\hline Genovese & $\begin{array}{l}0.55 \\
(0.39-0.83)\end{array}$ & $\begin{array}{l}6.67 \\
(3.43-17.84)\end{array}$ & 1.18 & 0.35 & 0.841 \\
\hline Sweet Dani & $\begin{array}{l}0.94 \\
(0.85-1.08)\end{array}$ & $\begin{array}{l}2.04 \\
(1.63-2.93)\end{array}$ & 3.80 & 5.65 & 0.057 \\
\hline 'Cinnamom' x 'Maria Bonita' & $\begin{array}{l}0.66 \\
(0.61-0.74)\end{array}$ & $\begin{array}{l}1.16 \\
(0.98-1.51)\end{array}$ & 5.20 & 5.87 & 0.052 \\
\hline 'Genovese' x 'Maria Bonita' & $\begin{array}{l}0.57 \\
(0.50-0.65)\end{array}$ & $\begin{array}{l}2.04 \\
(1.52-3.39)\end{array}$ & 2.32 & 5.87 & 0.051 \\
\hline 'Sweet Dani' x 'Maria Bonita' & $\begin{array}{l}0.71 \\
(0.68-0.76)\end{array}$ & $\begin{array}{l}1.16 \\
(1.04-1.34)\end{array}$ & 6.10 & 1.86 & 0.603 \\
\hline Linalool & $\begin{array}{l}1.15 \\
(1.11-1.21)\end{array}$ & $\begin{array}{l}1.45 \\
(1.35-1.63)\end{array}$ & 12.56 & 0.17 & 0.92 \\
\hline (E)-methyl cinnamate & $\begin{array}{l}0.14 \\
(0.11-0.17)\end{array}$ & $\begin{array}{l}0.76 \\
(0.54-1.20)\end{array}$ & 1.69 & 1.86 & 0.61 \\
\hline Citral & $\begin{array}{l}1.73 \\
(1.66-1.81)\end{array}$ & $\begin{array}{l}2.28 \\
(2.12-2.52)\end{array}$ & 10.63 & 1.53 & 0.53 \\
\hline \multicolumn{6}{|l|}{ S. zeamais } \\
\hline Maria Bonita & $\begin{array}{l}2.50 \\
(2.35-2.68)\end{array}$ & $\begin{array}{l}4.93 \\
(4.36-5.81)\end{array}$ & 4.36 & 4.97 & 0.172 \\
\hline Cinnamom & $\begin{array}{l}3.66 \\
(3.47-3.85)\end{array}$ & $\begin{array}{l}5.99 \\
(5.46-6.87)\end{array}$ & 5.96 & 2.62 & 0.269 \\
\hline Genovese & $\begin{array}{l}3.13 \\
(2.85-3.41)\end{array}$ & $\begin{array}{l}7.13 \\
(6.09-9.04)\end{array}$ & 3.57 & 4.49 & 0.104 \\
\hline
\end{tabular}


Toxicity of the essential...

\begin{tabular}{|c|c|c|c|c|c|}
\hline Sweet Dani & $\begin{array}{l}2.18 \\
(2.05-2.31)\end{array}$ & $\begin{array}{l}3.57 \\
(3.27-4.05)\end{array}$ & 5.97 & 3.05 & 0.213 \\
\hline 'Cinnamom' x 'Maria Bonita' & $\begin{array}{l}2.31 \\
(2.04-2.53)\end{array}$ & $\begin{array}{l}4.61 \\
(4.17-5.29)\end{array}$ & 4.26 & 4.71 & 0.093 \\
\hline 'Genovese' x 'Maria Bonita' & $\begin{array}{l}4.14 \\
(4.02-4.26)\end{array}$ & $\begin{array}{l}5.52 \\
(5.28-5.87)\end{array}$ & 10.25 & 3.40 & 0.333 \\
\hline 'Sweet Dani' x 'Maria Bonita' & $\begin{array}{l}2.77 \\
(2.66-2.87)\end{array}$ & $\begin{array}{l}3.82 \\
(3.62-4.09)\end{array}$ & 9.18 & 3.71 & 0.154 \\
\hline Linalool $^{3}$ & $\begin{array}{l}2.85 \\
(2.74-2.97)\end{array}$ & $\begin{array}{l}4.44 \\
(4.03-5.15)\end{array}$ & 6.61 & 4.25 & 0.37 \\
\hline (E)-methyl cinnamate & $\begin{array}{l}0.34 \\
(0.22-0.48)\end{array}$ & $\begin{array}{l}7.91 \\
(5.42-12.99)\end{array}$ & 0.94 & 3.97 & 0.60 \\
\hline $\mathrm{Citral}^{3}$ & $\begin{array}{l}2.69 \\
(2.52-2.87)\end{array}$ & $\begin{array}{l}4.37 \\
(3.94-5.04)\end{array}$ & 6.06 & 4.53 & 0.10 \\
\hline
\end{tabular}

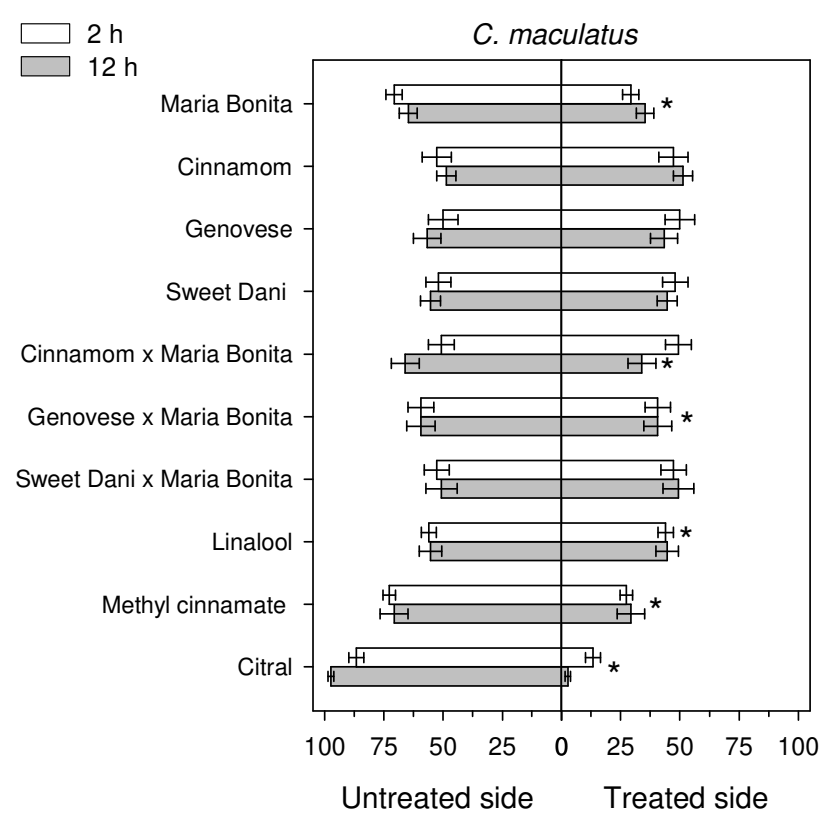

COSTA, A. S. et al.

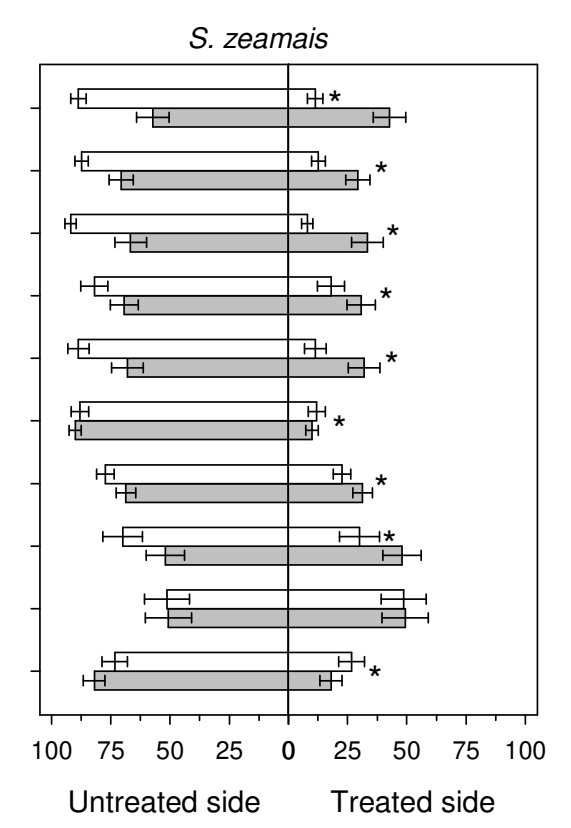

Figure 1. Repellency of $O$. basilicum essential oils and their major compounds applied at two exposure times to C. maculatus and S. zeamais.

*Significant difference between the number of individuals on treated and untreated sides $(\mathrm{P}<0.05)$.

\section{DISCUSSION}

The chemical analysis of essential oils of basil cultivars and hybrids showed monoterpenes and sesquiterpenes. The major chemical compounds found in the essential oils of $O$. basilicum cultivars and hybrids were linalool, (E)-methyl cinnamate, and citral (geranial + neral), already reported as having insecticidal activity (KNAAK; FIUZA, 2010; BARITAUX et al., 1992).

The genus Ocimum is known for its insecticidal properties due to the diversification of compounds in its essential oil (PANDEY et al., 2014). The essential oil of $O$. basilicum may contain eugenol, methyl eugenol, methyl chavicol, estragole, (E)-methyl cinnamate, citral, and linalool
(MIELE et al., 2001; KLIMÁNKOVÁ et al., 2008; BHAVYA, CHANDU, DEVI, 2018), which have insecticide action (KEITA et al., 2001; POPOVIĆ et al., 2006; BHAVYA, CHANDU, DEVI, 2018). Cultivars hybridization affected qualitatively and quantitatively the essential oils chemical composition. The compounds E-isocitral, geranyl propanoate, and germacrene A were only identified in the hybrids.

The analysis of the toxicity of the hybrids on $C$. maculatus and $S$. zeamais revealed that 'Genovese' x 'Maria Bonita' was more toxic to $C$. maculatus, whereas 'Cinnamom' $\mathrm{x}$ 'Maria Bonita' was more toxic to $S$. zeamais. This result suggests that the different composition of the essential oil of these hybrids influenced the greater toxicity to 
insects. The essential oil of the hybrid 'Genovese' $x$ 'Maria Bonita' had linalool, 1,8-cineol, methyl chavicol, and citral (general and geranial) as major compounds. Other compounds were detected at lower proportions (camphor, (E)-caryophyllene, $\alpha$ humulene, neryl propanoate, geranyl propanoate, beta-selinene, bicyclogermacrene, germacrene A) in the essential oil of this hybrid. The essential oil of 'Cinnamon' $\mathrm{x}$ 'Maria Bonita' had linalool, 1,8cineole, (E) and (Z)- methyl cinnamate as major compounds, and $\beta$-elemene was only identified in the hybrid.

It is inferred, therefore, that the insecticidal action of these essential oils may occur by additive and/or synergistic effects between compounds, both major and minor compounds (BAKKALI et al., 2008). These effects are common in terpenes, hydrophobic compounds that have synergistic effects on other compounds, solubilizing them and allowing their passage through the cell membranes (RATTAN, 2010).

However, some essential oils of the hybrids did not have some of the compounds identified in that of the parents (cultivars). This fact was observed in the hybrid 'Cinnamom' x 'Maria Bonita', where some compounds found in the cultivars (geranyl acetate, $\beta$-selinene, bicyclogermacrene, 1,10-di-epi-cubenol, and epi- $\alpha$-cadinol) were not detected in the essential oil of the hybrid. Even so, the essential oil of this hybrid was the most toxic to S. zeamais, being $58 \%$ more toxic to this species than that of cultivar Cinnamom. Thus, quantitative changes and the decrease of antagonistic effects of compounds absent in the essential oil of the hybrid may explain the higher toxicity of this oil. In fact, the monoterpene (E)-methyl cinnamate was the most toxic to both insects.

The insecticidal activity of methyl cinnamate has been reported by several authors (NOUR et al., 2009; DEKKER et al., 2011; KWON et al., 2011, FUJIWARA VERIFICAR NOME DO AUTOR et al., 2017). This compound is found in the essential oils of the cultivar 'Cinnamom' and hybrid 'Cinnamom' x 'Maria Bonita' at concentrations of $48.45 \%$ and $43.59 \%$, respectively. Thus, the high toxicity of the essential oil of this hybrid is due, at least in part, to the reduction of the antagonistic effects of the compounds absent in its essential oil.

The essential oil of $O$. basilicum and its major compounds had insecticidal activity against C. maculatus and S. zeamais, being the latter more less susceptible to the compounds. The higher tolerance of $S$. zeamais is possibly associated with the more efficient metabolization of these compounds by detoxifying enzymes (BACCI et al., 2007) since this species is subject to greater selective pressure by insecticides (RIBEIRO et al., 2003).

The toxicity of essential oils is related to the penetration of their compounds into insects through structures known as spiracles (SUGIURA et al., 2008). The penetration through insect spiracles is the fastest and most efficient way for these compounds to reach the probable site of action, causing symptoms such as hyperactivity, tremors, and paralysis (ZHU et al., 2003). Previous studies have attributed the toxicity of plant essential oils to several mechanisms, e.g., the action in sites such as cytochrome P450 (BACCI et al., 2007); the calcium channels modulated by gamma-aminobutyric acid GABA (ISMAN, 2006); and the action of octopamine (ENAN 2001 and 2005). However, the mechanism acting on $S$. zeamais and $C$. maculatus has not been confirmed yet, which requires further studies on the biochemical effects of these substances on the body of the insect.

Some authors have reported the toxicity of $O$. basilicum essential oil on C. maculatus (KEITA et al., 2000; PASCUAL-VILLALOBOS et al., 2003; ALVES et al., 2015) and S. zeamais (MATTA et al., 2010). However, no study has analyzed the toxicity of the essential oils of the hybrids tested in this work against $C$. maculatus and $S$. zeamais. The hybridization occurred by crossing basil cultivars, which provided a variety of compounds different quantities, resulting in different chemical composition when comparing hybrids and parents (COSTA et al., 2014 and 2016). These findings provide new essential oil profiles with insecticidal activity for the promising bioinsecticides market.

Results showed that the essential oils were more repellent to $S$. zeamais than $C$. maculatus. They also suggest that the greater repellency of $S$. zeamais was due to the greater capacity of the olfactory sensilla located in several parts of the body of this insect, which detect the odor released by the essential oils (GULLAN; CRANSTON, 2008; JAYASEKARA et al., 2005).

Isolated monoterpenes had different effects on insect behavior. Citral and (E)-methyl cinnamate were the most and least repellent compounds, respectively. These findings are relevant since different management strategies can be used for these pests by repelling the insects in grains not yet attacked or causing mortality at initial infestations.

In summary, the present work confirmed the toxicity of the essential oils of basil cultivars and hybrids to $S$. zeamais and $C$. maculatus. The essential oil of cultivar Genovese was more toxic to 
C. maculatus, and the essential oil of cultivar Sweet Dani was more toxic to $S$. zeamais. The hybrid 'Genovese' x 'Maria Bonita' was more toxic to $C$. maculate, and the hybrid 'Cinnamom' $\mathrm{x}$ 'Maria Bonita' was more toxic to $S$. zeamais. (E)-methyl cinnamate was the most toxic major compound to both insect species. Regarding repellency, the essential oils of cultivars, hybrids, and monoterpenes were repellent to $S$. zeamais, except for (E)-methyl cinnamate. The repellency effect was lower against $C$. maculatus, and citral was the most repellent compound.

\section{ACKNOWLEDGMENTS}

This study was financed in part by the Conselho Nacional de Desenvolvimento Científico e Tecnológico - Brasil (CNPq), the Fundação de Apoio à Pesquisa e a Inovação Tecnológica do Estado de Sergipe (Fapitec/SE) - Brasil, the Coordenação de Aperfeiçoamento de Pessoal de Nível Superior - Brasil (CAPES - Finance Code 001), the Financiadora de Estudos e Projetos - Brasil (FINEP).

RESUMO: Os óleos essenciais surgem como alternativa aos inseticidas sintéticos no controle das pragas de grãos armazenados. A toxicidade e a repelência dos óleos essenciais de quatro cultivares e três híbridos de manjericão e dos monoterpenos linalol, citral e (E)-cinamato de metila foram avaliadas nas pragas de grãos armazenados Callosobruchus maculatus e Sitophillus zeamais. Os óleos essenciais da cultivar Genovese e do híbrido 'Genovese' x 'Maria Bonita' foram mais tóxicos para C. maculatus. Já para S. zeamais, os óleos essenciais das cultivar Sweet Dani e do híbrido 'Cinnamom' x 'Maria Bonita' apresentaram maior toxicidade. Dentre os monoterpenos, o (E)-cinamato de metila foi o mais tóxico para ambas as pragas. Foram necessários 0,14 e $0,34 \mu \mathrm{L} \cdot \mathrm{mL}^{-1}$ para matar $50 \%$ da população de $C$. maculatus e $S$. zeamais. Todos os óleos essenciais das cultivares, dos híbridos e dos monoterpenos foram repelentes a $S$. zeamais, com exceção do (E)cinamato de metila. Já para $C$. maculatus, este efeito foi reduzido, sendo o citral o composto mais repelente. Nos resultados demonstram o potencial inseticida dos óleos essenciais de $O$. basilicum e seus monoterpenos para o controle de pragas de grãos armazenados.

PALAVRAS-CHAVE: Lamiaceae. Botanical insecticides. Monoterpene. Cowpea seed beetle. Maize weevil. TRADUZIR

\section{REFERENCES}

ABBOTT, W. S. A method of computing the effectiveness of an insecticide. Journal of Economic Entomology, v.18, p. 265-267, 1925. https://dx.doi.org/10.1093/jee/18.2.265a.

ADAMS, R.P. Identification of Essential Oil Components by Gas Chro-matography/Mass Spectroscopy, $4^{\text {th }}$ ed., Allured: Carol Stream. 2007. 804p.

ALVES, M. S.; SANTOS, D. P.; SILVA, L. C. P.; PONTES, E. G.; SOUZA, M. A. A. Essential Oils Composition and Toxicity Tested by Fumigation Against Callosobruchus maculatus (Coleoptera: Bruchidae) Pest of Stored Cowpea. Revista Virtual de Química, Niterói, v. 7, n. 6, p. 2387-2399, Oct. 2015. http://dx.doi.org/10.5935/1984-6835.20150142

AMARAL, C. L. F.; SILVA, A. B. Melhoramento Biotecnológico de Plantas Medicinais. Revista Biotecnologia, Ciência e Desenvolvimento, Gióas, v. 30, n. 1, p.55-59, Jan/Jun. 2003.

ASAWALAM, E. F.; EMOSAIRUE, S. O.; HASSANALI, A. Essential oil of Ocimum grattissimum (Labiatae) as Sitophilus zeamais (Coleoptera: Curculionidae) protectant. African Journal of Biotechnology, Nairobi, v. 7, n. 20, p. 3771-3776, Oct. 2008. https://dx.doi.org/10.5897/AJB08.491

AVESTISYAN, A.; MARKOSIAN, A.; PETROSYAN, M.; SAHAKYAN, N.; BABAYAN, A.; ALOYAN, S.; TRCHOUNIAN, A. Chemical composition and some biological activities of the essential oils frm basil Ocimum differente cultivars. BMC Complementary and Alternative Medicine, v.17, n. 60, p. 1-8, Jan. 2017. https://doi.org/10.1186/s12906-017-1587-5 
Toxicity of the essential...

COSTA, A. S. et al.

BACCI, L.; CRESPO, A. L.; GALVAN, T. L.; PEREIRA, E. J.; PICANÇO, M. C.; SILVA, G. A.; CHEDIAK, M. Toxicity of insecticides to the sweetpotato whitefly (Hemiptera: Aleyrodidae) and its natural enemies. Pest Management Science, West Sussex, v. 6, n.7, p. 699-706, May. 2007. https://dx.doi.org/10.1002/ps.1393

BAKKALI, F.; AVERBECK, S.; AVERBECK, D.; IDAOMAR, M. Biological effects of essential oils - A review. Food and Chemical Toxicology, Catalunha, v. 46, n. 2, p. 446-475, Fev. 2008.

https://dx.doi.org/10.1016/j.fct.2007.09.106

BARITAUX, O.; RICHARD, H. J.; DERSBESY, M. Effects of drying and storage of herbs and spices on the essential oil. Part I. Basil, O. basilicum L. Flavour and Fragrance Journal, Suiça, v. 7, n. 4, p. 267-271, Oct. 1992. https://dx.doi.org/10.1002/ffj.2730070507

BHAVYA, M.L.; CHANDU, A.G.S.; DEVI, S. S. Ocimum tenuiflorum oil, a potential insecticide against rice weevil with anti-acetylcholinesterase activity. Industrial Crops \& Products, v. 126, n.15, p. 434-439, Dec. 2018. https://doi.org/10.1016/j.indcrop.2018.10.043

BLANK, A. F.; CARVALHO FILHO, J. L. S.; SANTOS NETO, A. L.; ALVES, P. B.; ARRIGONI-BLANK, M. F.; SILVA-MANN, R.; MENDONÇA, M. C. Caracterização morfológica e agronômica de acessos de manjericão e alfavaca. Horticultura Brasileira, Brasília, v. 22, n. 1, p. 113-116, 2004.

http://dx.doi.org/10.1590/S0102-05362004000100024

BLANK, A. F.; SOUZA, E. M.; PAULA, J. W. A.; ALVES, P. B. Comportamento fenotípico e genotípico de populações de manjericão. Horticultura Brasileira, Brasília, v. 28, n. 3, p, 305-310, Jul/Sep. 2010.

http://dx.doi.org/10.1590/S0102-05362010000300011

CASTRO-ÁLVAREZ, F. F.; WILLIAM, M., BERGVINSON, D. J.; GARCÍA-LARA, S. Genetic mapping of QTL for maize weevil resistance in a RIL population of tropical maize. Theoretical and Applied Genetics, New York, v. 128, n. 3, p. 411-419, Mar. 2015. http://dx.doi.org/10.1007/s00122-014-2440-6

CHANG, C. L.; CHO, I. K.; LI, Q. X. Insecticidal activity of basil oil, trans-anethole, estragole, and linalool to adult fruit flies of Ceratitis capitata, Bactrocera dorsalis, and Bactrocera cucurbitae. Journal of Economic Entomology, Annapolis, v. 102, n. 1, p. 203-209, Feb. 2009. https://doi.org/10.1603/029.102.0129

COITINHO, R. L. B. C.; OLIVEIRA, J. V. de; GONDIM JÚNIOR, M. G. C.; CÂMARA, C. A. G. da. Toxicidade por fumigação, contato e ingestão de óleos essenciais para Sitophilus zeamais Motschulsky, 1885 (Coleoptera: Curculionidae). Ciência e Agrotecnologia, Lavras, v. 35, n. 1, p.172-178, Jan/Feb. 2011. http://dx.doi.org/10.1590/S1413-70542011000100022

COSTA, A. S.; ARRIGONI-BLANK, M. F.; SILVA M. A. A. P. da; ALVES, M. F.; SANTOS, D. A.; ALVES, P. B. The Impact of Hybridization on the Volatile and Sensorial Profile of Ocimum basilicum L. The Scientific World Journal, New York, v. 2014, n. 1, p. 1-9, Jan. 2014. http://dx.doi.org/10.1155/2014/824594

COSTA, A. S. da; ARRIGONI-BLANK, M. de F.; BLANK, A. F.; SILVA M. A. A. P.; PINTO, J. A. O.; SANTOS, D.A.; ALVES, P.B. Volatile profile of basil cultivars and hybrids. Boletín Latinoamericano y del Caribe de Plantas Medicinales y Aromáticas, Santiago, v. 15, n. 5, p. 315-322, Sep. 2016.

DEKKER, T.; IGNELL, R.; GHEBRU, M.; GLINWOOD, R.; HOPKINS, R. Identification of mosquito repellent odours from Ocimum forskolei. Parasites \& Vectors, United States, v.4, n. 1, p. 1-7, Sep. 2011. http://dx.doi.org/10.1186/1756-3305-4-183

ENAN, E. E. Insecticidal activity of essential oils: octopaminergic sites of action. Comparative Biochemistry and Physiology Part C: Toxicology \& Pharmacology, Flórida, v. 130, n. 3, p. 325-337, Nov. 2001. https://dx.doi.org/10.1016/S1532-0456(01)00255-1 
ENAN, E. E. Molecular and pharmacological analysis of an octopamine receptor from American cockroach and fruit fly in response to plant essential oils. Archives of Insect Biochemistry and Physiology, New York, v. 59, n. 3, p. 161-171, Jul. 2005. http://dx.doi.org/10.1002/arch.20076.

FINEY, D. J. Probit Analysis, 3rd edn. New York. 1971

FRANÇA, S. M.; OLIVEIRA, J. V.; ESTEVES FILHO, A. B.; OLIVEIRA, C. M. Toxicity and repellency of essential oils to Zabrotes subfasciatus (Boheman) (Coleoptera, Chrysomelidae, Bruchinae) in Phaseolus vulgaris L. Acta Amazonica, Amazônia, v. 42, n. 3, p. 381-386, Sep. 2012. http://dx.doi.org/10.1590/S004459672012000300010.

FUJIWARAA, G. M.; ANNIESB, V.; OLIVEIRAA, C. F. de, LARAA, R. A.; GABRIELA, M. M.; BETIMA, F. C. M.; NADALC, J. M.; FARAGOC, P. V.; DIASA, J. F. G.; MIGUELA, O. G.; MIGUELA, M. D.; MARQUESB, F. A.; ZANINA, S. M. W. Evaluation of larvicidal activity and ecotoxicity of linalool, methyl cinnamate and methyl cinnamate/linalool in combination against Aedes aegypti. Ecotoxicology and Environmental Safety, New York, v. 139, n.1, p. 238-244, Jan. 2017. https://dx.doi.org/10.1016/j.ecoenv.2017.01.046.

GOMES, S. P.; FAVERO, S. Avaliação de óleos essenciais de plantas aromáticas com atividade inseticida em Triatoma infestans (Klug, 1834) (Hemiptera: Reduviidae). Acta Scientiarium Health Sciences, Maringá, v. 33, n. 2, p.147-151, Jul-Dec. 2011. http://dx.doi.org/10.4025/actacihealthsci.v33i2.9531

GULLAN, P. J.; CRANSTON, P. S. Os insetos: um resumo de entomologia. 3 ed. São Paulo: Roca Ltda, 2008. 440p.

ISMAN, M. B. Botanical insecticides, deterrents, and repellents in modern agriculture and an increasingly regulated world. Annual Review of Entomology, United States, v. 51, n. 1, p. 45-66, Jul. 2006.

http://dx.doi.org/10.1146/annurev.ento.51.110104.151146

JAYASEKARA, T. K.; STEVENSON, P. C.; HALL, D. R.; BELMAIN, S. R. Effect of volatile constituents from Securidaca longepedunculata on insect pests of stored grain. Journal of Chemical Ecology, Karnataka, v. 31, n. 2, p. 303-313, Feb. 2005. http://dx.doi.org/ 10.1007/s10886-005-1342-0

JUNIOR-VIEGAS, C. Terpenos com atividade inseticida: uma alternativa para o controle químico de insetos. Química Nova, São Paulo. v. 26, n. 3, p. 390-400, Oct. 2003. http://dx.doi.org/10.1590/S0100 40422003000300017.

KEITA, S. M.; VINCENT, C.; SCHMIT, J.; RAMASWAMY, S.; BÉLANGER, A. Efect of various essential oils on Callosobruchus maculatus (F.) (Coleoptera: Bruchidae). Journal of Stored Products Research, Savannaha, v. 36, n. 4, p. 355-364, Oct. 2000. https:/dx./doi.org/10.1016/S0022-474X(99)00055-7

KEITA, S. M.; VINCENT, C.; SCHMIT, J.; ARNASON, J.T.; BÉLANGER, A. Efficacy of essential oil of Ocimum basilicum L. and $O$. gratissimum L. applied as an insecticidal fumigant and powder to control Callosobruchus maculatus (Fab.) [Coleoptera: Bruchidae]. Journal of Stored Products Research, v. 37, n. 4, Savannaha, p. 339-349, Oct. 2001. https://dx.doi.org/10.1016/S0022-474X(00)00034-5

KLIMÁNKOVÁ, E.; HOLADOVÁ, K.; HAJSLOVÁ, J.; CAJKA, T.; POUSTKA, J.; KOUDELA, M. Aroma profiles of five basil (Ocimum basilicum L.) cultivars grown under conventional and organic conditions. Food Chemistry, England,, v. 107, n. 1, p. 464-472, Mar. 2008. https://dx.doi.org/10.1016/j.foodchem.2007.07.062.

KNAAK, N.; FIUZA, L. M. Potencial dos óleos essenciais de plantas no controle de insetos e microrganismos. Neotropical Biology and Conservation, São Leopoldo, v. 5, n. 2, p. 120-132, Sep. 2010. http://dx.doi.org/doi: $10.4013 / \mathrm{nbc} .2010 .52 .08$ 
KWON, H. W.; KIM, S. I.; CHANG, K. S.; CLARK, J. M.; AHN, Y. J. Enhanced repellency of binary mixtures of Zanthoxylum armatum seed oil, vanillin, and their aerosols to mosquitoes under laboratory and field conditions. Journal of Medical Entomology, Washington, v. 48, n. 1, p. 61-66, Jan. 2011. https://dx.doi.org/10.1603/ME10042

LÓPEZ, M. D.; JORDÁN, M. J.; PASCUAL-VILLALOBOS, M. J. Toxic compounds in essential oils of coriander, caraway and basil active against stored rice pests. Journal of Stored Products Research, Savannaha, v. 44, n. 3, p. 273-278, Jul. 2008. https://dx.doi.org/10.1016/j.jspr.2008.02.005

LU, Y.; ZHONG, J.; WANG, Z.; LIU, F.; WAN, Z. Fumigation toxicity of allicin against three stored product pests. Journal of Stored Products Research. v. 55, p. 48-54, Oct. 2013.

https://doi.org/10.1016/j.jspr.2013.08.002

MATTA, F. B.; KERDCHOECHUEN, O.; LAOHAKUNJIT, N.; SINGKORNARD, S. Essential Oils from Six Herbal Plants for Biocontrol of the Maize Weevil. Hortscience, Alexandria, v. 45, n. 4, p. 592-598, Feb. 2010. http://dx.doi.org/10.21273/HORTSCI.45.4.592

MAZZONETTO, F.; VENDRAMIM, J. D. Efeito de Pós de Origem Vegetal sobre Acanthoscelides obtectus (Say) (Coleoptera: Bruchidae) em Feijão Armazenado. Neotropical Entomology, Londrina, v. 32, n. 1, p. 145149, Jan-Mar. 2003. http://dx.doi.org/10.1590/S1519-566X2003000100022

MIELE, M.; PONDERO, R.; CIARALLO, G.; MAZZEI, M. Methyl-eugenol in Ocimum basilicum L. cv Genovese gigante. Journal of Agricultural Food Chemistry, Washington, v. 49, n. 1, p. 517-521, Jan. 2001. http://dx.doi.org/10.1021/jf000865w

MISHRA, B. B.; TRIPATHI, S. P.; TRIPATHI, C. P. M. Repellent effect of leaves essential oils from Eucalyptus globulus (Mirtaceae) and Ocimum basilicum (Lamiaceae) against two major stored grain insect pests of Coleopterons. Natural Science, New York, v. 10, n. 2, p. 50-54, Jan. 2012. http://dx.doi.org/10.7537/marsnsj100212.09

NISHIDA, R.; BOWERS, W. S.; EVANS, P. H. Synthesis of highly active juvenile hormone analogs, juvocimene I and II, from the oil of sweet basil Ocimum basilicum L. Journal of Chemical Ecology, Karnataka, v. 10, n. 10, p. 1435-1450, Oct. 1984. http://dx.doi.org/10.1007/BF00990314

NOUR, A. H.; ELHUSSEIN, S. A.; NOUR, A. O.; NOUR, A. H.; YUSOFF, M. M. A study of the essential oils of four Sudanese accessions of basil (Ocimum basilicum L.) against Anopheles mosquito larvae. American Journal of Applied Sciences, United States, v. 6, n. 7, p.1359-1363, Jul. 2009.

http://dx.doi.org/10.3844/ajassp.2009.1359.1363

OJO, J. A.; OMOLOYE, A. A. Rearing the maize weevil, Sitophilus zeamais, on an artificial maize-cassava diet. Journal of Insect Science. v. 12, n. 69, p.1-9, Jun. 2012. http://dx.doi.org/ 10.1673/031.012.6901

OLIVEIRA, A. P.; SANTOS, A. A.; SANTANA, A. S.; LIMA, A. P. S.; MELO, C.R.; SANTANA, E. D. R.; SAMPAIO, T. S.; BLANK, A. F.; ARAÚJO, A. P.A.; CRISTALDO, P. F.; BACCI, L. Essential oil of Lippia sidoides and its major compound thymol: Toxicity and walking response of populations of Sitophilus zeamais (Coleoptera: Curculionidae). Crop Protection, v. 112, p. 33-38, Oct. 2018.

https://doi.org/10.1016/j.cropro.2018.05.011

OXENHAM, S. K.; SVOBODA, K. P.; WALTERS, D. R. Antifungal Activity of the Essential Oil of Basil ( Ocimum basilicum), v. 153, n.3, p. 174-180, Mar. 2005. https://doi.org/10.1111/j.1439-0434.2005.00952.x

PANDEY, A. K.; SINGH, P.; TRIPATHI, N. N. Chemistry and bioactivities of essential oils of some Ocimum species: an overview. Asian Pacific Journal of Tropical Biomedicine, China, v. 4, n. 9, p. 682-694, Sep. 2014. https://dx.doi.org/10.12980/APJTB.4.2014C77 
PASCUAL-VILLALOBOS, M. J.; BALLESTA-ACOSTA, M. C. Chemical variation in an Ocimum basilicum germplasm collection and activity of the essential oils on Callosobruchus maculates. Biochemical Systematics and Ecology, England, v. 31, n. 7, p. 673-679, Jul. 2003. https://dx.doi.org/10.1016/S0305-1978(02)00183-7.

POPOVIC, Z.; KOSTIC, M.; POPOVIC, S.; SKORIC, S. Bioactivities of essential oils from basil and sage to Sitophilus oryzae L. Biotechnology \& Biotechnological Equipment, England, v. 20, n. 1, p. 36-40, Apr. 2006. https://dx.doi.org/10.1080/13102818.2006.10817301

RATTAN, R. S. Mechanism of action of insecticidal secondary metabolites of plant origin. Crop Protection, United States of America, v. 29, n. 9, p. 913-920, Sep. 2010. https://doi.org/10.1016/j.cropro.2010.05.008

RESTELLO, R. M.; MENEGATT, C.; MOSSI, A. J. Efeito do óleo essencial de Tagetes patula L. (Asteraceae) sobre Sitophilus zeamais Motschulsky (Coleoptera, Curculionidae). Revista Brasileira de Entomologia, Curitiba, v. 53, n. 2, p. 304-307, Jun. 2009. http://dx.doi.org/10.1590/S0085-56262009000200015

RIBEIRO, B.; GUEDESA, R. N. C.; OLIVEIRA; E. E.; SANTOS; J. P. Insecticide resistance and synergism in Brazilian populations of Sitophilus zeamais (Coleoptera: Curculionidae). Journal of Stored Products

Research, Savannaha, v. 39, n. 1, p. 21-31, Dec. 2003. http://dx.doi.org/10.1016/S0022-474X(02)00014-0.

SAS Institute. SAS/STAT 9.2 User's Guide. 2008.

SUGIURA, M.; HORIBE, Y.; KAWADA, H.; TAKAGI, M. Insect spiracles as the main penetration route of pyrethroids. Pesticide Biochemistry and Physiology, United States, v. 91, n. 3, p. 135-140, Jul. 2008. https://doi.org/10.1016/j.pestbp.2008.03.001

VAN DEN DOOL, H.; KRATZ, P. D. A generalization of the retention index system including linear temperature programmed gas-liquid artition chromatography. Journal of Chromatography, United States, v. 11, n. 1, p. 463-471, Aug. 1963. https://dx.doi.org/10.1016/S0021-9673(01)80947-X.

ZHU, B. C. R.; HENDERSON, G.; YU, Y.; LAINE, R. A. Toxicity and Repellency of Patchouli Oil and Patchouli Alcohol against Formosan Subterranean Termites Coptotermes formosanus Shiraki (Isoptera: Rhinotermitidae). Journal of Agricultural Food Chemistry, Washington, v. 51, n. 16, p. 4585-4588, Jul. 2003. http://dx.doi.org/ 10.1021/jf0301495 